\title{
Fragile X mental retardation protein is involved in protein synthesis-dependent collapse of growth cones induced by Semaphorin-3A
}

\author{
Chanxia Li ${ }^{1}$, Gary J. Bassell ${ }^{1,2 *}$ and Yukio Sasaki ${ }^{1 *}$ \\ ' Department of Cell Biology, Emory University, Atlanta, GA, USA \\ 2 Department of Neurology, Emory University, Atlanta, GA, USA
}

Edited by:

Hollis Cline, Cold Spring Harbor, USA

Reviewed by:

Christine Holt, University of Cambridge,

UK

Justin Fallon, University of Pennsylvania, USA

\section{${ }^{*}$ Correspondence:}

Gary J. Bassell, Department of Cell Biology, School of Medicine, Emory University, Whitehead Biomedical

Research Bld. Room 415, 615 Michael Street, Atlanta, GA 30322, USA. e-mail: gbassel@emory.edu; Yukio Sasaki, Department of Cell Biology, School of Medicine, Emory University, Whitehead Biomedical Research Bld. Room 415, 615 Michael Street, Atlanta, GA 30322, USA. e-mail:yukio-sasaki@umin.ac.jp
Fragile $X$ syndrome, the most frequent form of familial mental retardation, is caused by mutation of the Fmr1 gene. Fmr1 encodes the fragile X mental retardation protein (FMRP), an mRNA binding protein regulating local, postsynaptic mRNA translation along dendrites necessary for long-term synaptic plasticity. However, recent studies on FMRP localization in axons and growth cones suggest a possible function in the regulation of local protein synthesis needed for axon guidance. Here, we have demonstrated that FMRP is involved in axonal and growth cone responses induced by the axon guidance factor, Semaphorin-3A (Sema3A). In cultured hippocampal neurons from wild type mice, Sema3A-induced growth cone collapse was protein synthesis-dependent. In contrast, Sema3A-induced growth cone collapse was attenuated in Fmr1 knock-out (KO) neurons and insensitive to protein synthesis inhibitors, suggesting that FMRP is involved in protein synthesis-dependent growth cone collapse. Sema3A increased phosphorylation of eukaryotic initiation factor $4 \mathrm{E}$ (elF4E), an indicator of local translation, in distal axons and growth cones of wild type, but not Fmr1 KO neurons. Furthermore, Sema3A rapidly induced a protein synthesis-dependent increase in levels of microtubule associated protein 1B (MAP1B) in distal axons of wild type neurons, but this response was attenuated in Fmr1 KO neurons. These results suggest a possible role of FMRP to regulate local translation and axonal protein localization in response to Sema3A. This study reveals a new link between FMRP and semaphorin signaling in vitro, and raises the possibility that FMRP may have a critical role in semaphorin signaling in axon guidance during brain development.

Keywords: semaphorin, fragile $\mathrm{X}$ mental retardation protein, mRNA binding protein, fragile $\mathrm{X}$ syndrome, local protein synthesis, axon guidance, microtubule associated protein $1 \mathrm{~B}$, growth cone

\section{INTRODUCTION}

Fragile X syndrome (FXS), the most common form of inherited mental retardation, is caused by mutation of the Fmr1 gene, encoding the fragile $\mathrm{X}$ mental retardation protein (FMRP) (Pieretti et al., 1991; Verkerk et al., 1991; O’Donnell and Warren, 2002; Penagarikano et al., 2007). FMRP is a selective RNA-binding protein implicated in regulating dendritic mRNA transport and local protein synthesis at synapses (Antar and Bassell, 2003; Jin and Warren, 2003; Bassell and Kelic, 2004; Bear et al., 2004; Jin et al., 2004; Willemsen et al., 2004). FMRP is known to associate with mRNAs, polyribosomes, and microRNA (miRNA) complexes (Brown et al., 2001; Darnell et al., 2001; Jin and Warren, 2003; Jin et al., 2004). Fmr1 knock-out (KO) mice have been used as model for FXS, and display synaptic impairments, seizure vulnerability, altered long term synaptic plasticity and defects of behavior and learning, indicating the essential roles of FMRP in governing normal brain function (The Dutch-Belgian Fragile X Consorthium, 1994; Oostra and Hoogeveen, 1997; Dobkin et al., 2000; Huber et al., 2002; Spencer et al., 2005; Dolen et al., 2007; Pfeiffer and Huber, 2009). To date, more than $400 \mathrm{mRNAs}$ have been reported to associate with FMRP (Brown et al., 2001; Darnell et al., 2001; Miyashiro et al., 2003; Zalfa et al., 2003). Many of these FMRP-associated mRNAs display abnormal polyribosome association in fragile $\mathrm{X}$ patient cells and in the brain of Fmrl KO mice (Brown et al., 2001; Zalfa et al., 2003; Lu et al., 2004), supporting the hypothesis that FMRP governs translation of its mRNA ligands. A prevailing hypothesis is that FMRP may regulate synaptic function by regulating transport of its mRNA targets into dendrites and also controling translation of these mRNAs locally at synapses, which in turn underlies longterm synaptic plasticity (Antar and Bassell, 2003; Jin and Warren, 2003; Bassell and Warren, 2008). Indeed, FMRP-mRNA complexes are transported in the form of RNA granules into neuronal processes in an activity- and microtubule-dependent manner (De Diego Otero et al., 2002; Antar et al., 2005; Dictenberg et al., 2008). FMRP interacts with different kinesins and has been show to function as an adapter for kinesin-1-dependent mRNA transport (Davidovic et al., 2007; Dictenberg et al., 2008). FMRP suppresses translation of its bound mRNAs in vitro, in transfected cells, and in the developing brain at basal levels (Laggerbauer et al., 2001; Li et al., 2001; Zalfa et al., 2003; Lu et al., 2004; Wang et al., 2004). Moreover, lack of FMRP impairs the stimulation of protein synthesis downstream of metabotropic glutamate receptors (mGluR) (Weiler et al., 1997; Hou et al., 2006; Muddashetty et al., 2007). Dysregulation of glutamate receptor-regulated protein synthesis at synapses is believed 
to underly many of the synaptic impairments in FXS (Bassell and Warren, 2008). However, it remains unclear whether FMRP may play a role in local protein synthesis downstream of other types of cell surface receptors (i.e. nonsynaptic) and the functional importance of such regulation in neuronal development.

While early attention focused on regulation of FMRP localization in dendrites and postsynaptically in spines (Antar et al., 2004), FMRP was later shown to be localized to axons and growth cones in cultured neurons (Antar et al., 2006; Hengst et al., 2006) and more recently detected in axons in vivo (Price et al., 2006; Murashov et al., 2007). FMRP granules and its target mRNA, encoding the microtubule associated protein (MAP) $1 \mathrm{~B}$, were localized in axonal growth cones of fully polarized neurons, in which axons were over $300 \mu \mathrm{m}$ long (Antar et al., 2006). High resolution analysis revealed FMRP colocalization and MAP1B mRNA within granules (Antar et al., 2005). FMRP granules also extended into filopodia of axonal growth cones. Furthermore, Fmr1 KO neurons showed reduced growth cone motility (Antar et al., 2006). These findings lead to an intriguing hypothesis that FMRP is involved in axon guidance via regulation of local translation in axons and growth cones. Actually, Drosophila dFmr1 mutants show axon guidance defects in interneurons in the CNS (Morales et al., 2002) and failure of $\beta$-lobe midlinecrossing in the mushroom body (Michel et al., 2004). More recently in the mouse model of FXS, axonal projections from layer 4 to 3 in the cortex were improperly regulated and defasciculated (Bureau et al., 2008). Collectively, these reports demonstrate that FMRP plays an important role in axon pathfinding, and suggest a possible role of FMRP in the regulation of local protein synthesis in axons and growth cones that is necessary for axon guidance.

There is accumulating evidence that local protein synthesis plays a critical role in axon guidance factor-induced growth cone turning (Campbell and Holt, 2001; Brittis et al., 2002; Ming et al., 2002; Piper and Holt, 2004; Lin and Holt, 2007). For example, attractive or repulsive turning responses induced by an attractive or repulsive axon guidance factor, netrin-1 or Sema3A, respectively, were blocked by protein synthesis inhibitors; this occurs even in growth cones and axons that had been separated from their cell bodies (Campbell and Holt, 2001). Bath application of Sema3A to retinal or dorsal root ganglia (DRG) neurons induced growth cone collapse in a protein synthesis-dependent manner (Campbell and Holt, 2001; Li et al., 2004). Moreover, exposure to netrin-1 or Sema3A triggered a burst of protein synthesis within growth cones and axons, as shown by a rapid phosphorylation of eukaryotic initiation factor- $4 \mathrm{E}$ (eIF-4E), and increased incorporation of labeled amino acids into proteins. In addition, Sema3A facilitates axonal transport of vesicles, even in axons isolated from their cell bodies, in a protein synthesis-dependent manner (Li et al., 2004). Numerous mRNAs have been shown to be localized and translated in axons (Willis et al., 2005; Willis and Twiss, 2006; Yoon et al., 2009). The axonal localization and translation of RhoA mRNA occurs in response to Sema3A stimulation, and was necessary for growth cone collapse (Wu et al., 2005). More recently, the levels of a few additional mRNAs in axons were shown to be regulated by Sema3A (Willis et al., 2007). These findings suggest that Sema3A signaling could promote axonal mRNA transport and local translation. However, it remains unclear which mRNA binding protein(s) might be involved in Sema3A-induced growth cone responses that depend on regulation of axonal mRNA. In consideration of the possible function of FMRP in axonal mRNA translation and growth cone motility and the known role of Sema3A in protein synthesisdependent guidance, we sought to investigate whether FMRP is involved in growth cone motility and axon guidance mediated by Sema3A. Sema3A is one of the major axon guidance factors in the hippocampus and cortex (Chedotal et al., 1998; Polleux et al., 1998), where Fmrl KO mice show several mutant phenotypes (Comery et al., 1997; Huber et al., 2002; Dolen et al., 2007).

In this study, we investigated the role of FMRP in Sema3Ainduced growth cone collapse of cultured hippocampal neurons. We demonstrate that Sema3A-induced growth cone collapse is attenuated, but protein synthesis-independent in Fmr1 KO neurons. Sema3A did not evoke phosphorylation of eIF4E, which is an indicator of local translation, in axons and growth cones in Fmr1 KO neurons. Sema3A increased MAP1B levels in distal axons from wild type neurons in a protein synthesis-dependent manner; this response was attenuated in Fmr1 KO. These findings reveal new links between FMRP, MAP1B and semaphorin signaling. FMRP may regulate presynaptic function in response to Sema3 $\mathrm{A}$ by regulating mRNA transport of its mRNA targets into axons and/or control of their translation in distal axons and growth cones, which in turn underlies protein synthesis-dependent axon guidance.

\section{MATERIALS AND METHODS HIPPOCAMPAL NEURON CULTURE AND COLLAPSE ASSAY}

Hippocampal neurons from wild type and Fmr1 KO mice were cultured as described previously (Antar et al., 2006; Muddashetty et al., 2007). Briefly, hippocampi were dissected from E17 embryos of wild type and Fmrl KO mice on a FVB background. After trypsinization, the cells were plated at 3000 cells $/ \mathrm{cm}^{2}$ on $10 \mu \mathrm{g} / \mathrm{ml}$ poly-L-lysine pre-coated coverslips, and cultured for 2-3 days in neurobasal media including GlutaMax and B27 supplement (Invitrogen). For the collapse assay, conditioned medium including alkaline phosphatase-fused mouse Sema3A (AP-Sema3A) or AP was prepared from $293 \mathrm{~T}$ cells transfected with the plasmid harboring AP-Sema3A or AP gene as previously described (Takahashi et al., 1997). AP-Sema3A concentration was determined based on AP activity. Conditioned medium containing AP-Sema3A (1 nM) was applied and then incubated for $30 \mathrm{~min}$, followed by glutaraldehyde fixation and staining with Alexa488-phalloidin. In some experiments, a protein synthesis inhibitor, anisomycin or cycloheximide $(25 \mu \mathrm{M})$, was applied $30 \mathrm{~min}$ before stimulation. To calculate the rate of growth cone collapse, over 100 axonal growth cones were analyzed in each experiment, and growth cones that had neither lamellipodia nor filopodia were scored as collapsed growth cones, as shown previously (Campbell and Holt, 2001; Li et al., 2004). Eight independent experiments were performed per genotype/treatment. As a control, the same volume of conditioned medium containing AP was applied for each experiment, and had no effect on the collapse assay. Housing, surgical and recording procedures were in accordance with the National Institutes of Health guidelines and the Emory University Institutional Animal Care and Use Committee.

\section{IMMUNOFLUORESCENCE}

Hippocamapal neurons from wild type and Fmr1 KO were stimulated by Sema3A ( $1 \mathrm{nM})$ and incubated for indicated periods. 
The neurons were fixed and processed for immunofluorescence (IF) using primary antibodies, followed by incubation with secondary antibodies labeled with Cy3 (Jackson ImmunoResearch), as described previously (Antar et al., 2006; Muddashetty et al., 2007). The following primary antibodies were used: rabbit polyclonal anti-phospho-eIF4E (Ser209; Cell Signaling Technologies) and rabbit polyclonal anti-MAP1B (gift from Dr Itzhak Fischer). The anti-MAP1B antibody was raised against a GST-fusion protein containing the central region of MAP1B [amino acids 1109-1360, (Ma et al., 1999)]. F-actin was visualized with Alexa488-phalloidin.

\section{MICROSCOPY AND IMAGING}

Immunofluorescence images were visualized using a $60 \times$ PlanNeofluar objective, $100 \mathrm{~W}$ mercury arc lamp, and HiQ bandpass filters (Chroma Tech) on a Nikon Eclipse TE300 inverted microscope. We selected hippocampal neurons with axons exceeding $100 \mu \mathrm{m}$ in length. Images were captured with a cooled CCD camera (Quantix, Photometrics) using IP Lab software (Scanalytics). For indicated experiments, Z-stacks were acquired (20 sections at $0.2 \mu \mathrm{m}$ each) using IP Lab software and deconvolved using a 3D blind algorithm (Imaris; Bitplane). To quantify fluorescent signals in axons, axon images (four per stack) were compressed, straightened and fluorescence intensities were measured using Imaris software. Volume rendering and $3 \mathrm{D}$ reconstruction were also processed using Imaris software. Mean IF intensity for MAP1B was analyzed within a defined region of interest (ROI) traced along a straightened axon in $10 \mu \mathrm{m}$ windows from the growth cone until $100 \mu \mathrm{m}$ (total 10 windows). Total IF intensity of the ROI was then divided by the area of the ROI to normalize for differences in axonal area. Each experiment was repeated a minimum of three times, imaging at least 10 primary axons per experiment (40 optical sections). Data was analyzed using an unpaired Student's $t$ test.

\section{RESULTS \\ SEMA3A-INDUCED GROWTH CONE COLLAPSE IS SUPPRESSED IN Fmr1 KO}

To investigate whether FMRP is involved in Sema3A-induced growth cone response, we examined growth cone collapse in wild type and Fmr1 KO hippocampal neurons in response to Sema3A, an important axon guidance factor that requires local protein synthesis to mediate its collapse effect (Campbell and Holt, 2001; Li et al., 2004). Although these previous studies have demonstrated that Sema3A-induced growth cone collapse is protein synthesis-dependent in DRG and retinal neurons, this has not yet been reported in hippocampal neurons. Sema3A (1 nM) induced growth cone collapse and resulted in complete loss of filopodia and lamellipodia in wild type hippocampal neurons after $30 \mathrm{~min}$ [Figure 1A: WT, Sema3A (+), Anisomycin (-)]. Sema3A application resulted in the collapse of over $80 \%$ of wild type growth cones (Figure 1B). However, in Fmr1 KO neurons, over $50 \%$ of growth cones showed almost no significant morphological change after Sema3A application [Figure 1A: Fmr1 $\mathrm{KO}$, Sema3A (+), Anisomycin (-)]. The collapse rate of Fmr1 KO neurons was attenuated to around 40\% (Figure 1B). This result suggests that growth cone collapse by Sema3A may be divided into FMRP-dependent and independent components. Next, we examined the effect of anisomycin, a protein synthesis inhibitor, on Sema3A-induced growth cone collapse. Anisomycin suppressed the rate of collapse to less than $40 \%$ in wild type neurons, while the inhibitor had no significant effect on the rate of collapse in Fmr1 KO neurons (Figure 1B). Similar results were obtained using another protein synthesis inhibitor, cyclohexamide (data not shown). The rate of collapse in wild type neurons with anisomycin was at a similar level to that of Fmrl KO neurons without the inhibitor, suggesting that FMRP is partly involved in protein synthesis-dependent growth cone collapse by Sema3A.

\section{SEMA3A-INDUCED PHOSPHORYLATION OF EIF4E IS ATTENUATED IN Fmr1 KO}

Sema3A treatment stimulates a local increase of phosphorylated eukaryotic translation initiation factor, eIF4E, whose phosphorylation is essential to initiate translation (Campbell and Holt, 2001; Li et al., 2004). To investigate the role of FMRP in translational control, we used immunofluorescence to examine levels of phosphorylated eIF4E in axons and growth cones in response to Sema3A. Sema3A increased the fluorescent intensities of phospho-eIF4E in growth cones and axons of wild type neurons, but not in Fmr1 KO neurons (Figure 2A). Quantitative analysis showed that Sema3A increased the immunofluorescence (IF) signal of phospho-eIF4E in axons and growth cones of wild type but not Fmr1 KO neurons (Figure 2Bab). In axons, the basal level of phosphorylation of eIF4E tended to be higher in Fmrl KO neurons than wild type, but no increase was seen after Sema3A stimulation (Figure 2Bb). These results suggest that Sema3A promotes local protein synthesis in distal axons and growth cones via FMRP.

\section{SEMA3A-INDUCED INCREASE IN MAP1B IN DISTAL AXONS IS SUPPRESSED IN Fmr1 KO NEURONS}

Having shown that FMRP is at least partly involved in growth cone collapse by Sema3A, we investigated whether Sema3A can influence axonal levels of MAP1B, since FMRP colocalizes with MAP1B mRNA in neuronal processes (Antar et al., 2005, 2006). To do this, we examined MAP1B levels along axons and growth cones by quantitative IF after Sema3A stimulation. The regulation of MAP1B by semaphorin has not been previously shown. At basal state, MAP1B was distributed mainly in proximal axons and dendrites, whereas distal axons had weaker signal, as did growth cones and the cell body (Figure 3A). At 5 min after Sema3A stimulation, MAP1B levels increased dramatically within distal axons in wild type neurons (Figure 3A). Of interest, MAP1B puncta possessing strong signals ("hot spots") were observed in distal axons. These hot spots are reminiscent of results showing local protein synthesis of CaMKII $\alpha$ in dendrites as hot-spots using a GFP reporter after BDNF stimulation (Aakalu et al., 2001) and findings of hot-spots of GFP signals for RhoA local translation after Sema3A stimulation (Wu et al., 2005). The MAP1B signal increased dramatically in distal axons of neurons with over $100-\mu \mathrm{m}$-long axons, compared to cell bodies and proximal axons (Figure 3A). MAP1B levels in growth cones tended to increase after Sema3A stimulation, with lower fluorescent intensities than observed in distal axons (data not shown). To illustrate the MAP1B signal intensity, distal axons $(0-100 \mu \mathrm{m}$ from growth cone stem) were straightened (Figure 3B) and the fluorescent 


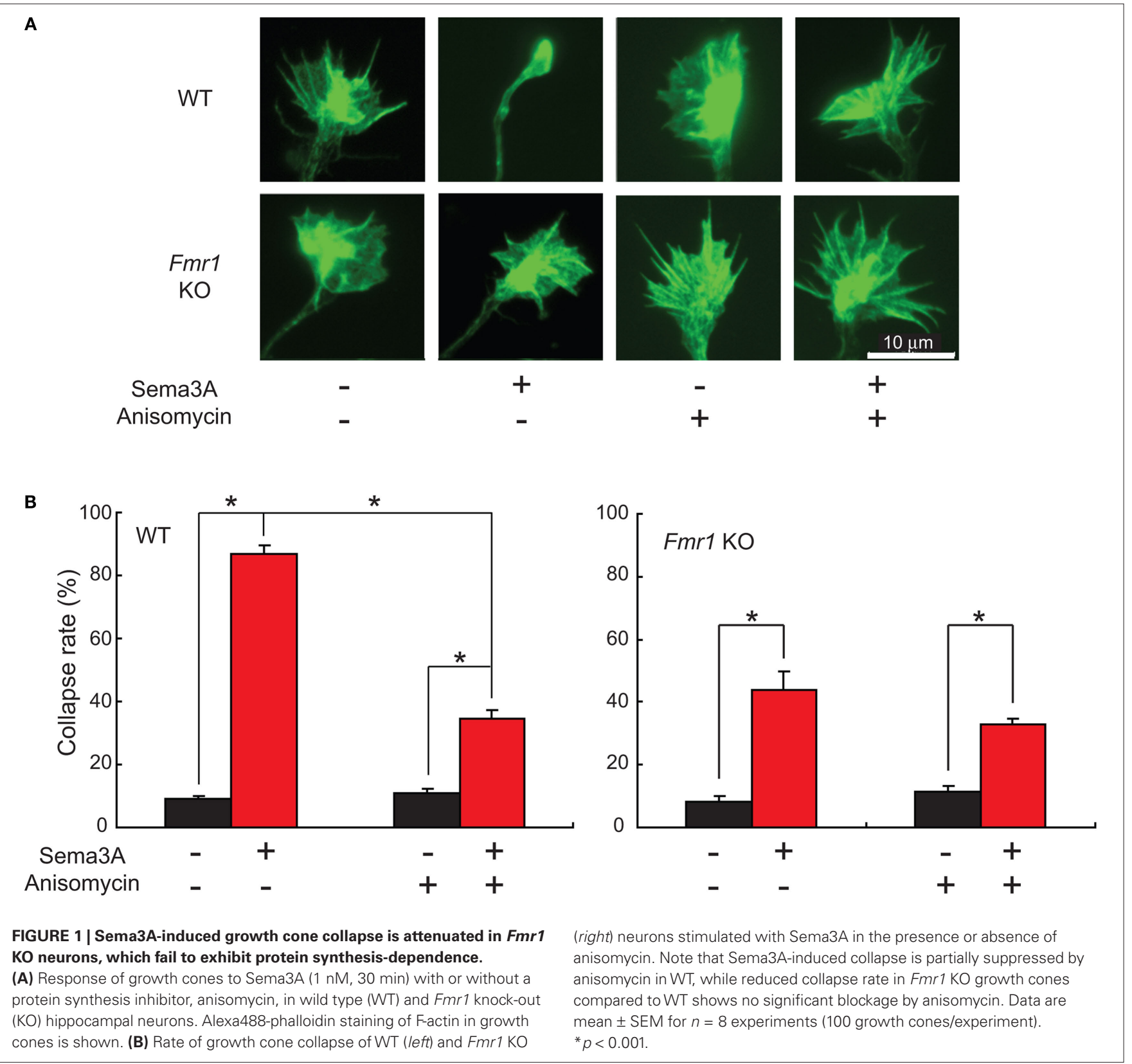

signals of MAP1B along axons were quantified. At 2 min after Sema3A stimulation, the fluorescent signal started to increase in distal axons of wild type neurons, and then the increase reached a maximal value at $5 \mathrm{~min}$ (Figures 3C,D). The signal for MAP1B started to decrease at $10 \mathrm{~min}$, and returned to the basal values at $30 \mathrm{~min}$. Of interest, Sema3A increased the MAP1B signal in distal axons at $5 \mathrm{~min}$ in wild type, but not significantly in Fmr1 KO neurons (Figures 3B,D), suggesting an FMRP-dependent increase in MAP1B levels in axons.

\section{SEMA3A INCREASES MAP1B LEVELS IN DISTAL AXONS IN A PROTEIN SYNTHESIS-DEPENDENT MANNER}

Next, we examined the effect of anisomycin on Sema3A-induced increase in MAP1B IF signal intensity in axons of wild type neurons.
Sema3A was applied to wild type hippocampal neurons with or without pre-incubation of anisomycin for $30 \mathrm{~min}$. Figure $4 \mathrm{~A}$ shows typical examples of straightened axons. Sema3A induced an increase in MAP1B signals in axons at $5 \mathrm{~min}$, while the increase was reduced in axons pre-incubated with anisomycin. The presence of anisomycin without Sema3A did not significantly affect MAP1B signal intensities in axons. Quantitative analysis of fluorescent intensities for MAP1B along the axon showed that the Sema3A-induced increase was blocked by anisomycin (Figure 4B). In distal axons, Sema3A increased the fluorescent intensities over 1.7 times, while the increase was not significant in distal axons treated with anisomycin (Figure 4C). This result suggests that Sema3A facilitated an increase in MAP1B levels in distal axons in a protein synthesis-dependent manner. Taken together, these data 

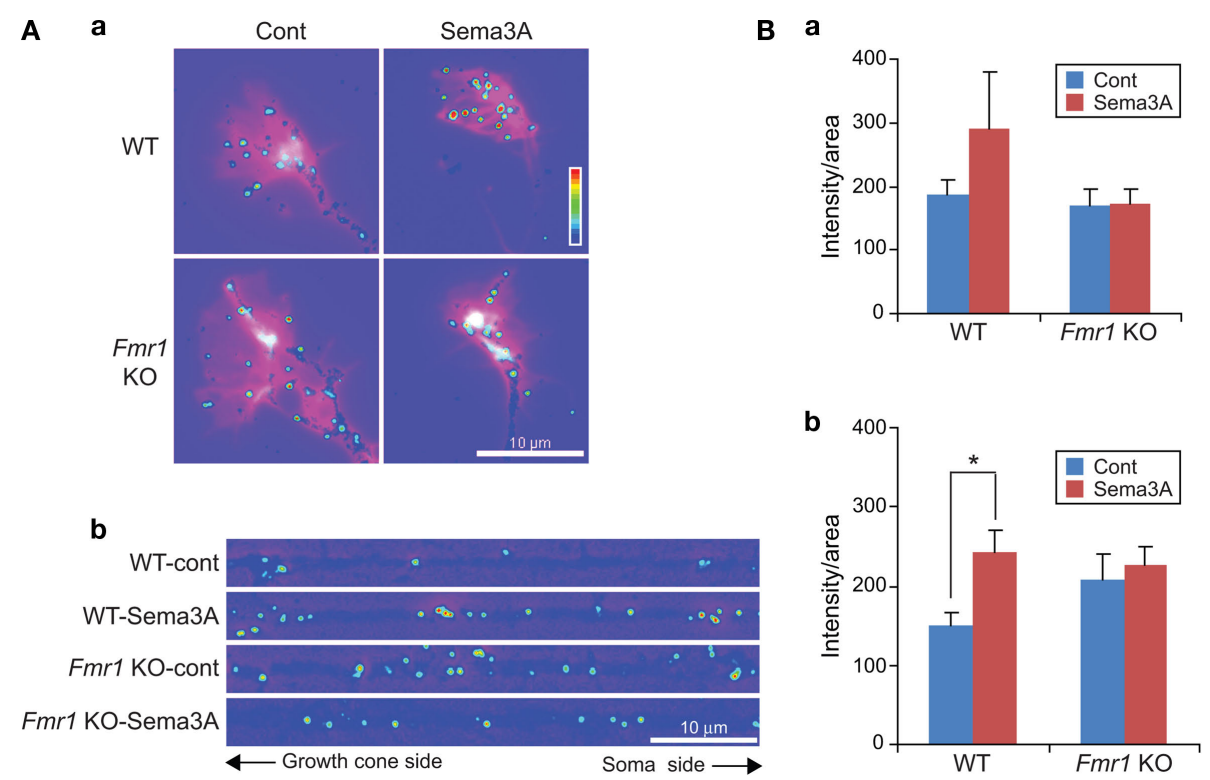

FIGURE 2 | Phosphorylation of elF4E by Sema3A is attenuated in Fmr1 KO neurons. (A) Immunofluorescence (IF) images of anti-phospho-elF4E (Ser209) antibody staining on growth cones (a) and straightened axons (b) treated with or without $1 \mathrm{nM}$ Sema3A for 5 min in WT and Fmr1 KO neurons. The color heat-map bar indicates the intensity of MAP1B IF signal from lowest (purple) to highest (red). Alexa488-phalloidin staining of F-actin in growth cones is illustrated by white color. (B) Fluorescent intensities of the growth cones (a) and straightened axons (b) in WT neurons and Fmr1 KO neurons treated under the condition as described in (A). Data are mean \pm SEM for $n=10,{ }^{*} p<0.05$. Note that increase in phosphoelF4E IF by Sema3A in WT is not observed in Fmr1 $\mathrm{KO}$ neurons.
A
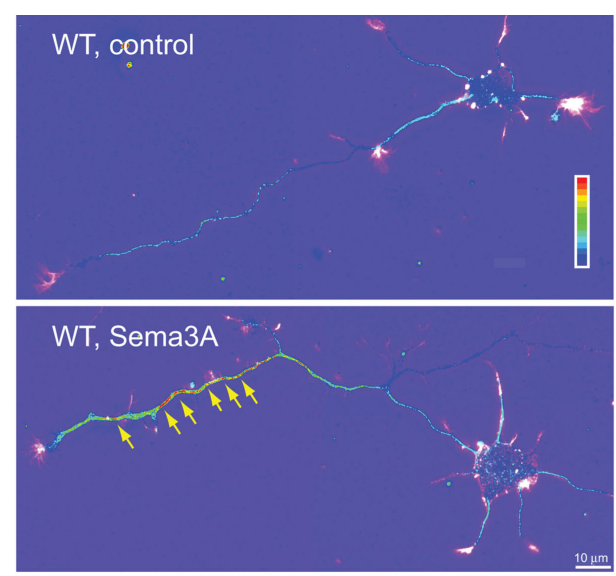

B

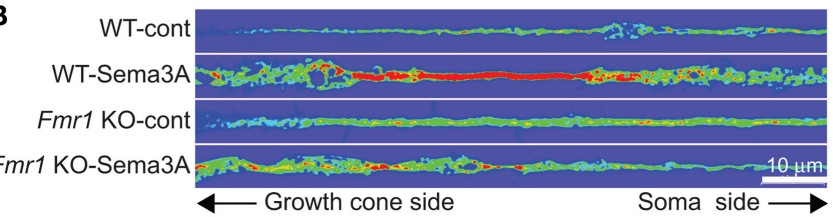

C

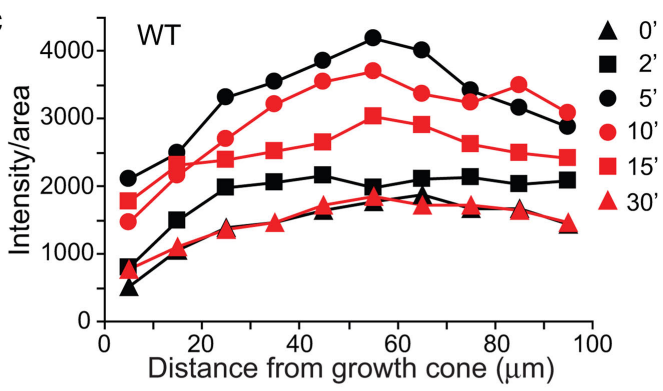

D

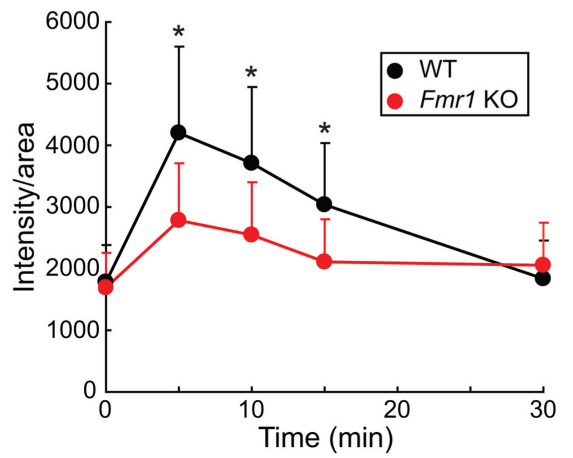

FIGURE 3 | Sema3A-induced increase in MAP1B in distal axons is suppressed in $\boldsymbol{F m r 1}$ KO neurons. (A) Sema3A (1 nM, 5 min) induced a local increase in MAP1B IF signal in WT axons. The color heat-map bar indicates the intensity of MAP1B IF signal from lowest (purple) to highest (red). Hot spots (see text) are represented by yellow arrows. Alexa488-phalloidin staining of F-actin in growth cones is illustrated by white color. Scale bar, $10 \mu \mathrm{m}$. (B) MAP1B IF images of straightened axons $(0-100 \mu \mathrm{m}$ from growth cone stem) treated with or without Sema3A for 5 min in WT and Fmr1 KO neurons. (C) Fluorescent intensities of the straightened axons ( $n=10$ at each time point) in WT neurons at different time points. Data are mean \pm SEM. (D) Time course of average distal axon fluorescent intensities in (C) in WT and Fmr1 KO neurons $\left(n=10,{ }^{*} p<0.05\right)$. Note that the transient increase in MAP1B IF signal observed in WT after Sema3A stimulation is attenuated in Fmr1 KO. 
A

WT

Sema3A Aniso

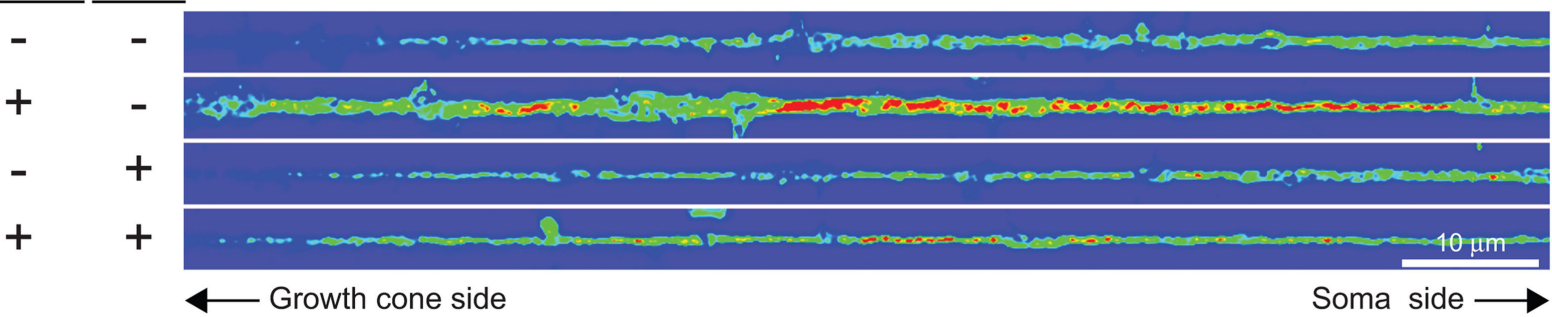

B

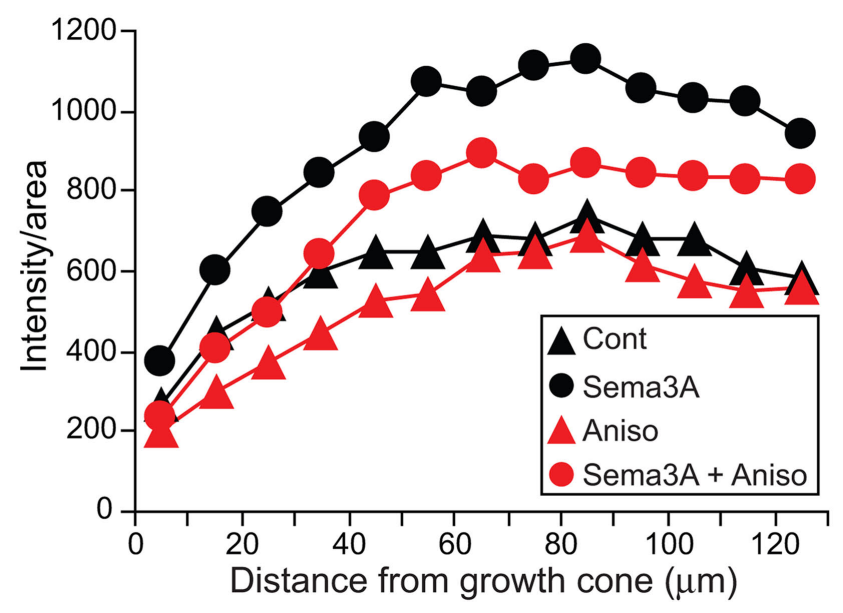

C

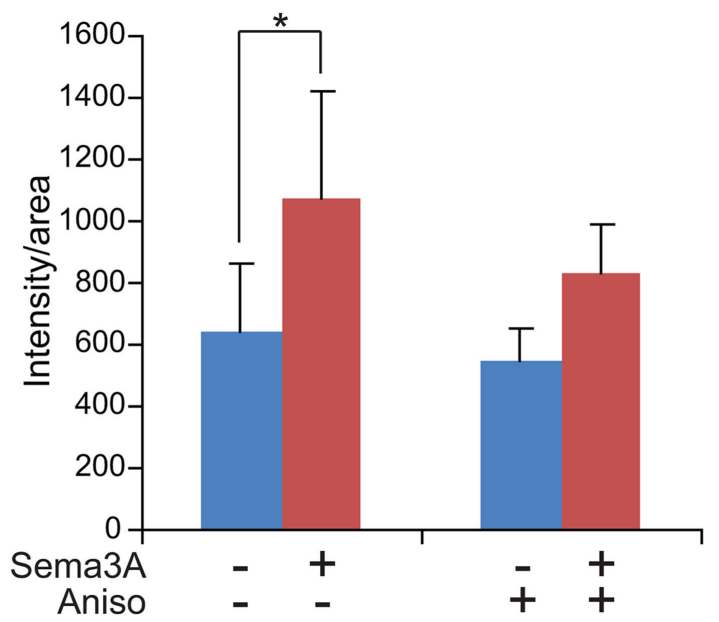

FIGURE 4 | Sema3A increased MAP1B levels in distal axons of wild type neurons in a protein synthesis-dependent manner. (A) MAP1B IF images of straightened axons treated with or without $1 \mathrm{nM}$ Sema3A for 5 min in WT neurons in the presence or absence of anisomycin (Aniso). (B) Fluorescent intensities of the straightened axons $(n=10)$ in WT neurons treated under the condition as described in (A). Data are mean \pm SEM. (C) Fluorescent intensities at distal axons in (B) $\left(n=10,{ }^{*} p<0.05\right)$. Note that increase in MAP1B IF by Sema3A is blocked by anisomycin. suggest the possibility that Sema3A-induced growth cone collapse is mediated by local MAP1B synthesis in distal axons and growth cones via FMRP.

\section{DISCUSSION}

Most research on FMRP has focused on postsynaptic functions in dendrites, which are regulated by FMRP-dependent local protein synthesis downstream of glutamate receptor signaling underlying long term synaptic plasticity. However, FMRP has been recognized to be localized in axons and growth cones in vitro (Antar et al., 2006; Hengst et al., 2006) and axons in vivo (Price et al., 2006; Murashov et al., 2007). Recently, FMRP has been detected presynaptically (Christie et al., 2009), consistent with a presynaptic function for FMRP (Hanson and Madison, 2007). These studies suggest a mechanism whereby FMRP may function in axonal signaling. Here, we have demonstrated that FMRP is involved in Sema3A-promoted growth cone collapse in a protein synthesis-dependent manner. To our knowledge, this is the first evidence showing a link between semaphorin signaling and FMRP. These findings serve to broaden the scope of FMRP-mediated local protein synthesis, consistent with the known diverse roles of FMRP in neuronal development (Bassell and Warren, 2008).

\section{FMRP IS INVOLVED IN PROTEIN SYNTHESIS-DEPENDENT GROWTH CONE COLLAPSE INDUCED BY SEMA3A}

Several groups have demonstrated that local protein synthesis is involved in growth cone responses induced by axon guidance factors (Campbell and Holt, 2001; Brittis et al., 2002; Ming et al., 2002; Lin and Holt, 2007). The general concept of local translation for axon guidance is that mRNA-RNA binding protein complex(s) are transported to axons and growth cones in response to axon guidance factors, followed by local translation from the mRNAs to promote axon steering. However, the precise role that mRNA binding proteins play in the regulation of axonal translation is unclear. In the case of netrin-1 and BDNF that promote attractive growth cone turning, these factors promote the asymmetric accumulation of $\beta$-actin mRNA and its binding protein, zipcode binding protein 1 (ZBP1; VgRBP, Xenopus homolog) in growth cones towards the attractive stimulation (Leung et al., 2006; Yao et al., 2006). Disruption of the interaction between ZBP1 and $\beta$-actin mRNA or new $\beta$-actin synthesis using antisense oligonucleotides impaired attractive growth cone turning towards a focal source of BDNF or netrin, suggesting a role for ZBP1/VgRBP in local protein synthesis in response to BDNF (Leung et al., 2006; Yao et al., 2006). The repulsive guidance factor, 
Sema3A, increased cofilin protein levels in growth cones, and since cofilin mRNA is associated with ZBP1/VgRBP, there may also be a role for $\mathrm{ZBP} 1 / \mathrm{VgRBP}$ in repulsive turning responses (Piper et al., 2006). However, it remains unclear precisely which RNA binding protein(s) play a role in growth cone behaviors in response to repulsive axon guidance factors like Sema3A.

In this study, we demonstrated that the growth cone collapse response induced by Sema3A is attenuated in Fmr1 KO neurons. Sema3A-induced eIF4E phosphorylation was also suppressed in Fmr1 KO neurons. These data suggest that FMRP is involved in a Sema3A-promoted growth cone response via local protein synthesis. Since several lines of evidence show that FMRP transports mRNAs and regulates translation of mRNAs locally in dendritic spines for plasticity of synaptic transmission, like long term depression (LTD) (Antar and Bassell, 2003; Bear et al., 2004; Pfeiffer and Huber, 2009), similar mechanisms to regulate local translation may underlie axon guidance involving FMRP.

\section{AXONAL MAP1B mRNA: A CANDIDATE LIGAND FOR FMRP-DEPENDENT TRANSLATION IN AXONS AND GROWTH CONES UNDERLYING AXON GUIDANCE}

Which mRNA(s) are probable targets of FMRP-involved in Sema3A-regulated protein synthesis in axons and growth cones? Among more than 400 mRNAs idendified as FMRP-associated mRNAs (Brown et al., 2001; Darnell et al., 2001; Miyashiro et al., 2003; Zalfa et al., 2003), MAP1B mRNA is one of the most intriguing candidates for local translation for axon guidance because of the following reasons: (1) The MAP1B mRNA is colocalized with FMRP in axonal granules (Antar et al., 2006). (2) A G-quartet in the $5^{\prime} \mathrm{UTR}$ of MAP1B is known to bind FMRP directly in vitro (Darnell et al., 2001), and MAP1B mRNA is found to associate with FMRP and regulate translation during an early postnatal period of brain development (Brown et al., 2001; Zalfa et al., 2003; Lu et al., 2004). (3) The Drosophila homologue of FMRP, dFMRP, associates with the mRNA encoding futsch, the MAP1B orthologue, and dFMRP deficiency results in abnormal futsch expression, synaptic overgrowth at the neuromuscular junction (Zhang et al., 2001), defects in axonal pruning (Tessier and Broadie, 2008), and abnormal elaboration of neuronal circuitry in the Drosophila brain (Gonzalez-Billault et al., 2001; McBride et al., 2005). (4) MAP1B KO mice show axonal guidance defects in the corpus callosum and the hippocampal commissure (Meixner et al., 2000). However, there is no evidence whether MAP1B is translated locally in axons and growth cones by axon guidance factors. In this study, we found that MAP1B levels in distal axons increased in response to Sema3A in a protein synthesis- and FMRP-dependent manner. The MAP1B levels increased only in distal axons, but not proximal axons or cell bodies. These findings suggest that FMRP is involved in local protein synthesis of MAP1B in distal axons. Future work is needed to demonstrate that MAP1B mRNA is axonally translated and to identify cis-acting sequences that are regulated by FMRP. Fluorescent reporters for local translation (Aakalu et al., 2001; Wang et al., 2009) would provide a critical tool to test this hypothesis. Our findings for FMRP-dependent regulation of axonal MAP1B protein could also be explained by the protein synthesis-dependent transport of MAP1B into distal axons. Of interest, Sema3A facilitated axonal transport in a protein synthesis-dependent manner (Li et al., 2004).
Further study is necessary to determine how MAP1B accumulates very rapidly in distal axons in response to Sema3A in a protein synthesis-dependent manner.

One interesting related question is how newly synthesized/ accumulated MAP1B may contribute to the morphologic and cytoskeletal changes of distal axons and growth cones in response to Sema3A. MAP1B is a highly phosphorylated protein and is considered that mode 1 phosphorylation, only found in a defined developmental period, regulates flexibility of microtubules needed for steering (Goold and Gordon-Weeks, 2004; Riederer, 2007). It is an attractive idea that phosphorylation of newly- and locallysynthesized/accumulated MAP1B after Sema3A stimulation controls reorganization of microtubules, resulting in growth cone collapse and steering. Consistent with this idea, Sema3A activates Cdk5 and GSK3ß (Sasaki et al., 2002; Uchida et al., 2005), which phosphorylate MAP1B. However, it remains controversial which form of MAP1B, unphosphorylated or phosphorylated form, confers flexibility of microtubules. It will be important for future work to assess how newly synthesized/accumulated MAP1B may have a different phosphorylation status that could contribute to local cytoskeletal changes driving growth cone collapse. Lastly, since MAP1B is also known as an F-actin-binding protein as well as microtubule-binding protein (Togel et al., 1998), it is possible that local accumulation of MAP1B promotes changes in microfilament reorganization needed for growth cone collapse. Sema3A-induced growth cone collapse is likely a highly coordinated and complex process involving actin and tubulin remodeling.

\section{OTHER POSSIBLE MECHANISMS OF ALTERED SEMA3A SIGNALING IN Fmr1 KO}

Our observations of deficient Sema3A-induced phosphorylation of eIF4E in axons from Fmrl KO suggest that there may be widespread alteration in translational regulation in growth cones, as has been evident already at the synapse. Therefore, it will be important to assess how several mRNAs may be dysregulated at the growth cone in Fmrl $\mathrm{KO}$ neurons in response to Sema3A and other guidance factors. The Twiss lab has shown that at least 11 mRNAs (Vimentin, $\alpha B$ crystallin, Hsp90, etc.) accumulate in axons of dorsal root ganglia after Sema3A stimulation (Willis et al., 2007), although they did not examine MAP1B mRNA. Of interest, RhoA mRNA is translated in growth cones after Sema3A stimulation (Wu et al., 2005). It will be very interesting if future work can demonstrate an interaction between FMRP and RhoA mRNA that may be partly responsible for protein synthesis-dependent growth cone collapse by Sema3A. However, it remains unclear whether FMRP is involved in accumulation and/or translation of these mRNAs induced by Sema3A or not. Meanwhile, FMRP is found to selectively bind $\sim 4 \%$ of the mRNA in the mammalian brain (Bassell and Warren, 2008), therefore, it is possible that translation of many other mRNAs may also have some contribution to protein synthesis- and FMRP-dependent collapse by Sema3A. One interesting candidate among FMRPassociated mRNAs is the mRNA encoding p116-RIP, an actinbinding protein (Dictenberg et al., 2008). The $\mathrm{N}$-terminal region of RIP bundles F-actin, while the $\mathrm{C}$-terminal region interacts directly with the regulatory myosin-binding subunits of myosin II phosphatase, MBS85 and MBS130 (Mulder et al., 2004). Because 
MBS binds to the active, GTP-bound form of RhoA (Kimura et al., 1996), RIP would mediate a RhoA signal for actin-remodeling. Possible activated translation of RIP mRNA in distal axons by FMRP-mediated derepression may regulate local microfilament reorganization for Sema3A-induced collapse. Sema3A may induce the local translation of both RhoA and RIP, and then RIP may convey Sema3A signal to RhoA for actin remodeling.

FMRP may also regulate cytoskeletal dynamics by interacting directly with some proteins. In Drosophila, mutations of CYFIP/ sra-1, the fly ortholog of the vertebrate FMRP-interacting proteins, CYFIP1 and CYFIP2, affect axons and synapses, much like mutations in $d F m r 1$ and in the Rho GTPase dRacl (Schenck et al., 2003). CYFIP/sra-1 interacts genetically and biochemically with $d F m r 1$ and $d R a c 1$. Therefore, it is possible that CYFIP functions as a bridge between FMRP and Rac1. Lack of FMRP may impair downstream regulation of Rac affecting the cytoskeleton. Alternatively, Rac-CYFIP interactions may directly influence FMRP-mediated protein synthesis.

There is accumulating evidence that signaling of group I mGluRs is exaggerated in Fmrl KO mice (Bear et al., 2004). Of interest to this study, the Raper group showed that the group I mGluR-specific agonist S-3,5-dihydroxyphenyl glycine (DHPG) suppressed growth cone collapse induced by several repulsive axon guidance factors, including Sema3A (Kreibich et al., 2004). This suppression is mediated by pertussis toxin-sensitive activation of protein kinase $\mathrm{A}$ and the subsequent inactivation of Rho (Kreibich et al., 2004). One interesting possibility is that the exaggerated mGluR signaling in Fmr1 KO may contribute to the phenotype of suppressed Sema3Ainduced collapse. However, there is no report so far showing that pertussis toxin-sensitive G-proteins or Rho is involved in mGluRmediated signaling of FMRP. Further work is necessary to examine possible interrelationships of exaggerated mGluR signaling and responsiveness to Sema3A. We favor a model whereby FMRP has direct functions downstream of several receptors to negatively regulate local protein synthesis. However, it is also possible that dysregulation in one receptor pathway may compromise another due to cross-talk between pathways.

\section{POSSIBLE AXONAL AND DENDRITIC PHENOTYPES IN Fmr1 MUTANTS RELATED TO SEMAPHORIN SIGNALING}

Future work is needed to characterize whether axonal phenotypes in FXS animal models can be attributed to defects in specific guidance factor signaling mechanisms in vivo. Although the Fmr 1

\section{REFERENCES}

Aakalu, G., Smith, W. B., Nguyen, N., Jiang, C., and Schuman, E. M. (2001). Dynamic visualization of local protein synthesis in hippocampal neurons. Neuron 30, 489-502.

Antar, L. N., Afroz, R., Dictenberg, J. B., Carroll, R. C., and Bassell, G. J. (2004). Metabotropic glutamate receptor activation regulates fragile $\mathrm{X}$ mental retardation protein and FMR1 mRNA localization differentially in dendrites and at synapses. J. Neurosci. 24, 2648-2655.

KO was reported to show defects in axonal projections from layer 4 to 3 in the cortex (Bureau et al., 2008), it is unknown so far whether these phenotypes are correspondent to those of semaphorin or semaphorin receptor mutants. However, recent studies suggest that FMRP may be involved in axon guidance and/or pruning mediated by semaphorin signaling. The $d F m r 1$ mutant in Drosophila is reported to show pruning defects of axons in the mushroom body, which is a primary learning/memory center in the Drosophila brain (Tessier and Broadie, 2008). Sema3A has axon pruning activity in hippocampal neurons in culture, and axon pruning defects in the hippocampal infrapyramidal bundle are observed in the semaphorin receptor mutants, Neuropilin-2 and Plexin-A3 KO (Bagri et al., 2003). These data suggest that semaphorins and FMRP may share the same signal transduction pathway for axonal pruning in vivo. In addition, Sema3A promotes spine maturation in cortical neurons in culture (Morita et al., 2006). In Fmr1 KO mice, more immature spines were observed in layer V pyramidal neurons (Comery et al., 1997). These findings also suggest a possible link between semaphorins and FMRP in spine development. For future research, it will be interesting to examine whether there are genetic interactions between semaphorin mutants and Fmrl for axon pruning and spine maturation.

In conclusion, these findings demonstrate a new role for FMRP to mediate Sema3A signaling via regulation of protein synthesis in vitro. This work broadens our perspective of FMRP function beyond the synapse, and predicts similar defects in dysregulated translation at the growth cone. Further work will be required to clarify FMRP-mediated mechanisms of local translational regulation underlying axon guidance and to identify phenotypic similarities in vivo between Fmrl and Sema3A mutants for axon guidance. Our findings have important implications for the identification of signaling pathways as new therapeutic targets to restore neuronal development and circuitry in FXS.

\section{ACKNOWLEDGMENTS}

This work was supported by National Institutes of Health Grants MH085617 and HD061344 to GB and the Neuronal Imaging Core of the Baylor/Emory Fragile X Research Center (HD024064). We thank Drs. Itzhak Fischer (Drexel University) and Yoshio Goshima for providing anti-MAP1B antibody and AP-Sema3A plasmid, respectively. We also thank Dr. Christina Gross (Emory University) for helpful discussions and critical reading.

(2006). Local functions for FMRP in axon growth cone motility and activity-dependent regulation of filopodia and spine synapses. Mol. Cell Neurosci. 32, 37-48.

Bagri, A., Cheng, H. J., Yaron, A., Pleasure, S. J., and Tessier-Lavigne, M. (2003). Stereotyped pruning of long hippocampal axon branches triggered by retraction inducers of the semaphorin family. Cell 113, 285-299.

Bassell, G. J., and Kelic, S. (2004). Binding proteins for mRNA localization and local translation, and their dysfunction in genetic neurological disease. Curr. Opin. Neurobiol. 14, 574-581.

Bassell, G. J., and Warren, S. T. (2008). Fragile X syndrome: loss of local mRNA regulation alters synaptic development and function. Neuron 60, 201-214.

Bear, M. F., Huber, K. M., and Warren, S. T. (2004). The mGluR theory of fragile $\mathrm{X}$ mental retardation. Trends Neurosci. 27, 370-377.

Brittis, P. A., Lu, Q., and Flanagan, J. G. (2002). Axonal protein synthesis provides a mechanism for localized 
regulation at an intermediate target. Cell 110, 223-235.

Brown, V., Jin, P., Ceman, S., Darnell, J. C., O'Donnell, W. T., Tenenbaum, S. A., Jin, X., Feng, Y., Wilkinson, K. D., Keene, J. D., Darnell, R. B., and Warren, S.T. (2001). Microarray identification of FMRP-associated brain mRNAs and altered mRNA translational profiles in fragile $\mathrm{X}$ syndrome. Cell 107, 477-487.

Bureau, I., Shepherd, G. M., and Svoboda, K. (2008). Circuit and plasticity defects in the developing somatosensory cortex of FMR1 knock-out mice. J. Neurosci. 28, 5178-5188.

Campbell, D. S., and Holt, C. E. (2001). Chemotropic responses of retinal growth cones mediated by rapid local protein synthesis and degradation. Neuron 32, 1013-1026.

Chedotal, A., Del Rio, J. A., Ruiz, M., He, Z., Borrell, V., de Castro, F., Ezan, F., Goodman, C. S., Tessier-Lavigne, M., Sotelo, C., and Soriano, E. (1998). Semaphorins III and IV repel hippocampal axons via two distinct receptors. Development 125, 4313-4323.

Christie, S. B., Akins, M. R., Schwob, J. E., and Fallon, J. R. (2009). The FXG: a presynaptic fragile $\mathrm{X}$ granule expressed in a subset of developing brain circuits. J. Neurosci. 29, 1514-1524.

Comery, T. A., Harris, J. B., Willems, P. J., Oostra, B. A., Irwin, S. A., Weiler, I. J., and Greenough, W. T. (1997). Abnormal dendritic spines in fragile $\mathrm{X}$ knockout mice: maturation and pruning deficits. Proc. Natl. Acad. Sci. U.S.A. 94, 5401-5404.

Darnell, J. C., Jensen, K. B., Jin, P., Brown, V., Warren, S. T., and Darnell, R. B. (2001). Fragile X mental retardation protein targets $\mathrm{G}$ quartet mRNAs important for neuronal function. Cell 107, 489-499.

Davidovic, L., Jaglin, X. H., LepagnolBestel, A. M., Tremblay, S., Simonneau, M., Bardoni, B., and Khandjian, E. W. (2007). The fragile $\mathrm{X}$ mental retardation protein is a molecular adaptor between the neurospecific KIF3C kinesin and dendritic RNA granules. Hum. Mol. Genet. 16, 3047-3058.

De Diego Otero, Y., Severijnen, L. A., van Cappellen, G., Schrier, M., Oostra, B., and Willemsen, R. (2002). Transport of fragile X mental retardation protein via granules in neurites of $\mathrm{PC} 12$ cells. Mol. Cell Biol. 22, 8332-8341.

Dictenberg, J. B., Swanger, S. A., Antar, L. N., Singer, R. H., and Bassell, G. J. (2008). A direct role for FMRP in activity-dependent dendritic mRNA transport links filopodial-spine morphogenesis to fragile X syndrome. Dev. Cell 14, 926-939.
Dobkin, C., Rabe, A., Dumas, R., El Idrissi, A., Haubenstock, H., and Brown, W. T. (2000). Fmrl knockout mouse has a distinctive strain-specific learning impairment. Neuroscience $100,423-429$.

Dolen, G., Osterweil, E., Rao, B. S., Smith, G. B., Auerbach, B. D., Chattarji, S., and Bear, M. F. (2007). Correction of fragile $\mathrm{X}$ syndrome in mice. Neuron 56, 955-962.

Gonzalez-Billault, C., Avila, J., and Caceres, A. (2001). Evidence for the role of MAP1B in axon formation. Mol. Biol. Cell 12, 2087-2098.

Goold, R. G., and Gordon-Weeks, P. R. (2004). Glycogen synthase kinase 3 beta and the regulation of axon growth. Biochem. Soc. Trans. 32, 809-811.

Hanson, J. E., and Madison, D. V. (2007). Presynaptic FMR1 genotype influences the degree of synaptic connectivity in a mosaic mouse model of fragile X syndrome. J. Neurosci. 27, 4014-4018.

Hengst, U., Cox, L. J., Macosko, E. Z., and Jaffrey, S. R. (2006). Functional and selective RNA interference in developing axons and growth cones. J. Neurosci. 26, 5727-5732.

Hou, L., Antion, M. D., Hu, D., Spencer, C. M., Paylor, R., and Klann, E. (2006). Dynamic translational and proteasomal regulation of fragile X mental retardation protein controls mGluRdependent long-term depression. Neuron 51, 441-454.

Huber, K. M., Gallagher, S. M., Warren, S. T., and Bear, M. F. (2002). Altered synaptic plasticity in a mouse model of fragile X mental retardation. Proc. Natl. Acad. Sci. U.S.A. 99, 7746-7750.

Jin, P., Alisch, R. S., and Warren, S. T. (2004). RNA and microRNAs in fragile X mental retardation. Nat. Cell Biol. 6 , 1048-1053.

Jin, P., and Warren, S. T. (2003). New insights into fragile $\mathrm{X}$ syndrome: from molecules to neurobehaviors. Trends Biochem. Sci. 28, 152-158.

Kimura, K., Ito, M., Amano, M., Chihara, K., Fukata, Y., Nakafuku, M., Yamamori, B., Feng, J., Nakano, T., Okawa, K., Iwamatsu, A., and Kaibuchi, K. (1996). Regulation of myosin phosphatase by Rho and Rho-associated kinase (Rho-kinase). Science 273, 245-248.

Kreibich, T. A., Chalasani, S. H., and Raper, J. A. (2004). The neurotransmitter glutamate reduces axonal responsiveness to multiple repellents through the activation of metabotropic glutamate receptor 1. J. Neurosci. 24, 7085-7095.

Laggerbauer,B., Ostareck,D., Keidel, E. M., Ostareck, L. A., and Fischer, Y. (2001).
Evidence that FMRP is a negative regulator of translation. Hum. Mol. Genet. 10, 329-338.

Leung, K. M., van Horck, F. P., Lin, A. C., Allison, R.,Standart, N., and Holt, C. E. (2006). Asymmetrical beta-actin mRNA translation in growth cones mediates attractive turning to netrin1. Nat. Neurosci. 9, 1247-1256.

Li, C., Sasaki, Y., Takei, K., Yamamoto, H., Shouji,M.,Sugiyama,Y.,Kawakami, T., Nakamura, F., Yagi, T., Ohshima, T., and Goshima, Y. (2004). Correlation between semaphorin3A-induced facilitation of axonal transport and local activation of a translation initiation factor eukaryotic translation initiation factor 4E. J. Neurosci. 24 , 6161-6170.

Li, Z., Zhang, Y., Ku, L., Wilkinson, K. D., Warren, S. T., and Feng, Y. (2001). The fragile $\mathrm{X}$ mental retardation protein inhibits translation via interacting with mRNA. Nucleic Acids Res. 29, 2276-2283.

Lin, A. C., and Holt, C. E. (2007). Local translation and directional steering in axons. EMBO J. 26, 3729-3736.

Lu, R., Wang, H., Liang, Z., Ku, L., O'Donnell, W. T., Li, W., Warren, S. T., and Feng, Y. (2004). The fragile X protein controls microtubule-associated protein 1B translation and microtubule stability in brain neuron development. Proc. Natl. Acad. Sci. U.S.A. 101, 15201-15206.

Ma, D., Chow, S., Obrocka, M., Connors, T., and Fischer, I. (1999). Induction of microtubule-associated protein 1B expression in Schwann cells during nerve regeneration. Brain Res. $823,141-153$.

McBride, S. M., Choi, C. H., Wang, Y., Liebelt, D., Braunstein, E., Ferreiro, D., Sehgal, A., Siwicki, K. K., Dockendorff, T. C., Nguyen, H. T., McDonald, T. V., and Jongens, T. A. (2005). Pharmacological rescue of synaptic plasticity, courtship behavior, and mushroom body defects in a Drosophila model of fragile $\mathrm{X}$ syndrome. Neuron 45, 753-764.

Meixner, A., Haverkamp, S., Wassle, H., Fuhrer, S., Thalhammer, J., Kropf, N., Bittner, R. E., Lassmann, H., Wiche, G., and Propst, F. (2000). MAP1B is required for axon guidance and is involved in the development of the central and peripheral nervous system. J. Cell Biol. 151, 1169-1178.

Michel, C. I., Kraft, R., and Restifo, L. L. (2004). Defective neuronal development in the mushroom bodies of Drosophila fragile X mental retardation 1 mutants. J. Neurosci. 24, 5798-5809.

Ming, G. L., Wong, S. T., Henley, J., Yuan, X. B., Song, H. J., Spitzer, N. C., and Poo, M. M. (2002). Adaptation in the chemotactic guidance of nerve growth cones. Nature 417, 411-418.

Miyashiro, K. Y., Beckel-Mitchener, A., Purk, T. P., Becker, K. G., Barret, T., Liu, L., Carbonetto, S., Weiler, I. J., Greenough, W. T., and Eberwine, J. (2003). RNA cargoes associating with FMRP reveal deficits in cellular functioning in Fmrl null mice. Neuron $37,417-431$.

Morales, J., Hiesinger, P. R., Schroeder, A. J., Kume, K., Verstreken, P., Jackson, F. R., Nelson, D. L., and Hassan, B. A. (2002). Drosophila fragile X protein, DFXR, regulates neuronal morphology and function in the brain. Neuron 34, 961-972.

Morita, A., Yamashita, N., Sasaki, Y., Uchida, Y., Nakajima, O., Nakamura, F., Yagi, T., Taniguchi, M., Usui, H., Katoh-Semba, R., Takei, K., and Goshima, Y. (2006). Regulation of dendritic branching and spine maturation by semaphorin3A-Fyn signaling. J. Neurosci. 26, 2971-2980.

Muddashetty, R. S., Kelic, S., Gross, C., $\mathrm{Xu}, \mathrm{M}$., and Bassell, G. J. (2007). Dysregulated metabotropic glutamate receptor-dependent translation of AMPA receptor and postsynaptic density-95 mRNAs at synapses in a mouse model of fragile $\mathrm{X}$ syndrome. J. Neurosci. 27, 5338-5348.

Mulder, J., Ariaens, A., van den Boomen, D., and Moolenaar, W. H. (2004).p116Rip targets myosin phosphatase to the actin cytoskeleton and is essential for RhoA/ROCK-regulated neuritogenesis. Mol. Biol. Cell 15, 5516-5527.

Murashov, A. K., Chintalgattu, V., Islamov, R. R., Lever, T. E., Pak, E. S., Sierpinski, P. L., Katwa, L. C., and Van Scott, M. R. (2007). RNAi pathway is functional in peripheral nerve axons. FASEB. J. 21, 656-670.

O'Donnell, W. T., and Warren, S. T. (2002). A decade of molecular studies of Fragile X Syndrome. Annu. Rev. Neurosci. 25, 315-338.

Oostra, B.A., and Hoogeveen, A. T. (1997). Animal model for fragile $\mathrm{X}$ syndrome. Ann. med. 29, 563-567.

Penagarikano, O., Mulle, J. G., and Warren, S. T. (2007). The pathophysiology of fragile x syndrome. Annu. Rev Genomics Hum. Genet. 8, 109-129.

Pfeiffer, B. E., and Huber, K. M. (2009). The state of synapses in fragile $\mathrm{X}$ syndrome. Neuroscientist [Epub ahead of print].

Pieretti, M., Zhang, F. P., Fu, Y. H., Warren, S. T., Oostra, B. A., Caskey, C. T., and Nelson, D. L. (1991). Absence of expression of the FMR-1 gene in fragile X syndrome. Cell 66, 817-822. 
Piper, M., Anderson, R., Dwivedy, A., Weinl, C., van Horck, F., Leung, K. M., Cogill,E., and Holt,C. (2006).Signaling mechanisms underlying Slit2-induced collapse of Xenopus retinal growth cones. Neuron 49, 215-228.

Piper, M., and Holt, C. (2004). RNA translation in axons. Annu. Rev. Cell Dev. Biol. 20, 505-523.

Polleux, F., Giger, R. J., Ginty, D. D., Kolodkin, A. L., and Ghosh, A. (1998). Patterning of cortical efferent projections by semaphorin-neuropilin interactions. Science 282, 1904-1906.

Price, T. J., Flores, C. M., Cervero, F., and Hargreaves, K. M. (2006). The RNA binding and transport proteins staufen and fragile $\mathrm{X}$ mental retardation protein are expressed by rat primary afferent neurons and localize to peripheral and central axons. Neuroscience 141, 2107-2116.

Riederer, B. M. (2007). Microtubuleassociated protein $1 \mathrm{~B}$, a growth-associated and phosphorylated scaffold protein. Brain Res. Bull. 71, 541-558.

Sasaki, Y., Cheng, C., Uchida, Y., Nakajima, O., Ohshima, T., Yagi, T., Taniguchi, M., Nakayama, T., Kishida, R., Kudo, Y., Ohno, S., Nakamura, F., and Goshima, Y. (2002). Fyn and Cdk5 mediate semaphorin$3 \mathrm{~A}$ signaling, which is involved in regulation of dendrite orientation in cerebral cortex. Neuron 35, 907-920.

Schenck, A., Bardoni, B., Langmann, C., Harden, N., Mandel, J. L., and Giangrande, A. (2003). CYFIP/Sra1 controls neuronal connectivity in Drosophila and links the Racl GTPase pathway to the fragile $\mathrm{X}$ protein. Neuron 38, 887-898.

Spencer, C. M., Alekseyenko, O., Serysheva, E., Yuva-Paylor, L. A., and Paylor, R. (2005). Altered anxietyrelated and social behaviors in the Fmrl knockout mouse model of fragile X syndrome. Genes Brain Behav. 4, 420-430.
Takahashi, T., Nakamura, F., and Strittmatter, S. M. (1997). Neuronal and non-neuronal collapsin-1 binding sites in developing chick are distinct from other semaphorin binding sites. J. Neurosci. 17, 9183-9193.

Tessier, C. R., and Broadie, K. (2008). Drosophila fragile X mental retardation protein developmentally regulates activity-dependent axon pruning. Development 135, 1547-1557.

The Dutch-Belgian FragileXConsorthium (1994). Fmr1 knockout mice: a model to study fragile $\mathrm{X}$ mental retardation. Cell 78, 23-33.

Togel, M., Wiche, G., and Propst, F. (1998). Novel features of the light chain of microtubule-associated protein MAP1B: microtubule stabilization, self interaction, actin filament binding, and regulation by the heavy chain. J. Cell Biol. 143, 695-707.

Uchida, Y., Ohshima, T., Sasaki, Y., Suzuki, H., Yanai, S., Yamashita, N., Nakamura, F., Takei, K., Ihara, Y., Mikoshiba, K., Kolattukudy, P., Honnorat, J., and Goshima, Y. (2005). Semaphorin3A signalling is mediated via sequential Cdk5 and GSK3beta phosphorylation of CRMP2: implication of common phosphorylating mechanism underlying axon guidance and Alzheimer's disease. Genes Cells $10,165-179$.

Verkerk, A. J., Pieretti, M., Sutcliffe, J. S., Fu, Y. H., Kuhl, D. P., Pizzuti, A., Reiner, O., Richards, S., Victoria, M. F., Zhang, F. P., Eussen, B. E., van Ommen G.-J. B., Blonden L. A. J., Riggins, G.J.,Chastain,J.L.,Kunst, C. B., Galjaard, H., Caskey, T., Nelson, D. L., Oostra, B., A., and Warren, S. T. (1991). Identification of a gene (FMR-1) containing a CGG repeat coincident with a breakpoint cluster region exhibiting length variation in fragile $\mathrm{X}$ syndrome. Cell 65, 905-914.

Wang, D. O., Kim, S. M., Zhao, Y., Hwang, H., Miura, S. K., Sossin, W. S., and Martin, K.C. (2009). Synapse- and stimulus-specific local translation during long-term neuronal plasticity. Science 324, 1536-1540.

Wang, H., Ku, L., Osterhout, D. J., Li, W., Ahmadian, A., Liang, Z., and Feng, Y. (2004). Developmentallyprogrammed FMRP expression in oligodendrocytes: a potential role of FMRP in regulating translation in oligodendroglia progenitors. Hum. Mol. Genet. 13, 79-89.

Weiler, I. J., Irwin, S. A., Klintsova, A. Y., Spencer, C. M., Eberwine, J., and Greenough, W. T. (1997). Fragile X mental retardation protein is translated near synapses. Proc. Natl. Acad. Sci. U.S.A. 94, 5395-5400.

Willemsen, R., Oostra, B. A., Bassell, G. J., and Dictenberg, J. (2004). The fragile $\mathrm{X}$ syndrome: from molecular genetics to neurobiology. Ment. Retard. Dev. Disabil. Res. Rev. 10, 60-67.

Willis, D., Li, K. W., Zheng, J. Q., Chang, J. H., Smit, A., Kelly, T., Merianda, T. T., Sylvester, J., van Minnen, J., and Twiss, J. L. (2005). Differential transport and local translation of cytoskeletal, injuryresponse, and neurodegeneration protein mRNAs in axons. J. Neurosci. 25, 778-791.

Willis, D. E., and Twiss, J. L. (2006). The evolving roles of axonally synthesized proteins in regeneration. Curr. Opin. Neurobiol. 16, 111-118.

Willis, D. E., van Niekerk, E. A., Sasaki, Y., Mesngon, M., Merianda, T.T., Williams, G. G., Kendall, M., Smith, D. S., Bassell, G. J., and Twiss, J. L. (2007). Extracellular stimuli specifically regulate localized levels of individual neuronal mRNAs. J. Cell Biol. 178, 965-980.

Wu,K.Y.,Hengst,U.,Cox,L.J.,Macosko, E. Z., Jeromin, A., Urquhart, E. R., and Jaffrey, S. R. (2005).Local translation of RhoA regulates growth cone collapse. Nature 436, 1020-1024.
Yao, J., Sasaki, Y., Wen, Z., Bassell, G. J. and Zheng, J. Q. (2006). An essential role for beta-actin mRNA localization and translation in $\mathrm{Ca}^{2+}$-dependent growth cone guidance. Nat. Neurosci. 9, 1265-1273.

Yoon, B. C., Zivraj, K. H., and Holt, C. E. (2009). Local translation and mRNA trafficking in axon pathfinding. Results Probl. Cell Differ. [Epub ahead of print].

Zalfa, F., Giorgi, M., Primerano, B., Moro, A., Di Penta, A., Reis, S., Oostra, B., and Bagni, C. (2003). The fragile $\mathrm{X}$ syndrome protein FMRP associates with $\mathrm{BC} 1 \mathrm{RNA}$ and regulates the translation of specific mRNAs at synapses. Cell 112, 317-327.

Zhang, Y. Q., Bailey, A. M., Matthies, H. J., Renden, R. B.,Smith,M.A.,Speese, S. D., Rubin, G. M., and Broadie, K. (2001). Drosophila fragileX-related gene regulates the MAP1B homolog Futsch to control synaptic structure and function. Cell 107, 591-603.

Conflict of Interest Statement: The authors declare that the research was conducted in the absence of any commercial or financial relationships that could be construed as a potential conflict of interest.

Received: 01 June 2009; paper pending published: 28 June 2009; accepted: 20 August 2009; published online: 15 September 2009.

Citation: Li C, Bassell GJ and Sasaki $Y$ (2009) Fragile X mental retardation protein is involved in protein synthesisdependent collapse of growth cones induced by Semaphorin-3A. Front. Neural Circuits 3:11. doi: 10.3389/neuro.04.011.2009 Copyright $\odot 2009$ Li, Bassell and Sasaki. This is an open-access article subject to an exclusive license agreement between the authors and the Frontiers Research Foundation, which permits unrestricted use, distribution, and reproduction in any medium, provided the original authors and source are credited. 